\title{
Competitiveness attributes of Small and Medium Enterprises (SMEs) in the global market (case study: garment SMEs in Tri Tunggal Village, Lamongan)
}

\author{
Issa Dyah Utami ${ }^{1, *}$, Trisita Novianti ${ }^{1}$ and Teuku Iqbal Dianta Romansa ${ }^{1}$ \\ ${ }^{1}$ Department of Industrial Engineering Indonesia, University of Trunojoyo, , 69162 Bangkalan, \\ Indonesia
}

\begin{abstract}
The center of small and medium enterprises (SMEs) of garment in Tritunggal Village, Lamongan produces t-shirts, jackets, sport costumes and school uniforms, and other garment products. The SMEs have a potential opportunity to develop their marketing strategy so that they can compete with similar industries and obtain profit from the national market. This study aims to identify main criteria of marketing strategy to compete with other garment industries at the national level. The criteria determine the improvement of competitiveness of the SMEs. A review of literature was conducted to identify the criteria. Then, three respondents from the SMEs and the government were asked to score the criteria based on their preferences, using a questionnaire. Purposive sampling was used to choose the respondets Responses were selected and weighted using Analytical Network Process (ANP) and Super decision software was used to obtain the highest weight of criteria. Outputs of the software show that the role of government in developing garment industry has the highest weight, which is 0.11665 . The results of this study could help the SMEs and the government plan a strategy in improving the SMEs' capability in entering the global market.
\end{abstract}

\section{Introduction}

Tri Tunggal Village in Lamongan Regency has become a garment industry center that produces t-shirts, jackets, sport costumes, school uniforms and other garment products. The garment small and medium enterprises (SMEs) are the largest industrial garment center in Lamongan. Currently, these SMEs have customers from local and outside the area of Lamongan. However, they have not been able to penetrate the national market. To compete in the national market, the SMEs should conduct preparation and improvement in terms of internal and the external factors. Competition in the national market will be more difficult as they have to compete with other garment SMEs located in other cities and from all

\footnotetext{
* Corresponding author: i.d.utami@trunojoyo.ac.id
} 
around Indonesia [1]. The government must also participate in increasing the sales of SMEs and help manage some appropriate strategies to improve the SMEs' performance [2].

This study aims to determine the criteria which positively affect the competitiveness of the garment SMEs. Information as output of this study could be used to formulate strategies and propose a strategic priority to improve the competitiveness. This research is expected to contribute to the garment SMEs in improving the quality of their products in order to achieve a competitive advantage in the global market. The results of this study are useful for the government, particularly in formulating policies for managing the center of SMEs. The research focuses on the competitiveness of the garment SMESs in Lamongan in penetrating the global market. The internal competition between the SMEs in Tri Tunggal garment center was not studied.

\section{Research Method}

Analytic Network Process (ANP) [2-3] was used to analyze the internal and external competitiveness criteria of the garment SMEs in Tri Tunggal Village, Lamongan. Data collection was carried out through observations in the field in order to obtaine the description of the research setting [4-5]. A questionnaire which consists of criteria, internal and external attributes to improve the competitiveness of SMEs, was formed based on a review of the literature.

Table 1. Competitiveness criteria and attributes of the garment SMEs

\begin{tabular}{|c|c|c|c|c|}
\hline & $\begin{array}{ll} & \text { Criteria } \\
\end{array}$ & Attributes & Description & Authors \\
\hline \multirow[t]{5}{*}{1} & \multirow[t]{5}{*}{$\begin{array}{l}\text { Human } \\
\text { resources }\end{array}$} & $\begin{array}{l}\text { Motivation of } \\
\text { entrepreneurship }\end{array}$ & $\begin{array}{l}\text { motivation of entrepreneurs in } \\
\text { entrepreneurship }\end{array}$ & Abdullah, 2011 [2] \\
\hline & & Minimum wage rates & $\begin{array}{l}\text { minimum wage rates received } \\
\text { by workers }\end{array}$ & Lestari, 2013 [7] \\
\hline & & $\begin{array}{l}\text { The abundance of the } \\
\text { national product workforce }\end{array}$ & $\begin{array}{l}\text { The large number of human } \\
\text { resources }\end{array}$ & Nurzamzami, 2014 [8] \\
\hline & & managerial skills & $\begin{array}{l}\text { a good managerial skill to } \\
\text { improve sales and } \\
\text { sustainability of the } \\
\text { organization }\end{array}$ & Lestari, 2013 [7] \\
\hline & & Experienced worker & $\begin{array}{l}\text { National products supported } \\
\text { by workforce' experience }\end{array}$ & Nurzamzami, 2014 [8] \\
\hline \multirow[t]{4}{*}{2} & \multirow[t]{2}{*}{ Financial } & Product pricing & $\begin{array}{l}\text { Product pricing influenced by } \\
\text { national determination on } \\
\text { financial competitiveness and } \\
\text { affordable prices }\end{array}$ & Nurzamzami, 2014 [8] \\
\hline & & Investment value & the magnitude of investment & Sugiarsana, 2011 [9] \\
\hline & \multirow[t]{2}{*}{$\begin{array}{l}\text { Material } \\
\text { resources }\end{array}$} & Ease of obtaining materials & $\begin{array}{l}\text { the ease in obtaining raw } \\
\text { materials }\end{array}$ & Nurzamzami, 2014 [8] \\
\hline & & Product quality & the quality of products & Lestari, 2013 [7] \\
\hline 4 & Technology & The technology used & $\begin{array}{l}\text { the technology used by } \\
\text { manufacturers }\end{array}$ & Nurzamzami, 2014 [8] \\
\hline 5 & Marketing & $\begin{array}{l}\text { Preferences of the } \\
\text { consumers }\end{array}$ & $\begin{array}{l}\text { consumers' choice on a } \\
\text { particular product }\end{array}$ & Nurzamzami, 2014 [8] \\
\hline
\end{tabular}




\begin{tabular}{|c|c|c|c|c|}
\hline & & Product image & $\begin{array}{l}\text { product image which is well } \\
\text { known by public }\end{array}$ & Nurzamzami, 2014 [8] \\
\hline & & Market Expectations & market expectations & Abdullah, 2011 [2] \\
\hline & & Utilization of technology & $\begin{array}{l}\text { the utilization of technology } \\
\text { in marketing }\end{array}$ & Jesika, 2012 [10] \\
\hline 6 & Strategy & Innovation & innovation or design strategy & Jesika, 2012 [10] \\
\hline & & Business competition & $\begin{array}{l}\text { strategy in competing with } \\
\text { similar businesses }\end{array}$ & Nurzamzami, 2014 [8] \\
\hline 7 & Production & Production Capacity & $\begin{array}{l}\text { production capacity able to } \\
\text { meet consumer demand }\end{array}$ & Sugiarsana, 2011 [9] \\
\hline 8 & $\begin{array}{l}\text { The role of } \\
\text { government }\end{array}$ & $\begin{array}{l}\text { The development of } \\
\text { garment industry }\end{array}$ & $\begin{array}{l}\text { the role of government in } \\
\text { helping develop the garment } \\
\text { industry }\end{array}$ & Lestari, 2013 [7] \\
\hline & & $\begin{array}{l}\text { The role of government in } \\
\text { giving financial support }\end{array}$ & $\begin{array}{l}\text { The role of government in } \\
\text { helping provide access to } \\
\text { financial institutions for } \\
\text { lending capital and insurance }\end{array}$ & Lestari (2013) [7] \\
\hline
\end{tabular}

This research applied purposive random sampling to choose respondents. The three respondents were the SMEs coordinators and the government. The questionnaire was validated by using face validity method to the respondents. The questionnaire contains eight criteria, which are human resources, financial, material resources, technology, marketing, strategy, production, and the role of government. The criteria were described into nineteen attributes adopted from several literatures that are considered to be related to the problems in the center of garment SMEs. The attributes are entrepreneurial motivation, the minimum wage level, the number of manpower, managerial ability, experienced worker, price determination, investment value, ease of obtaining raw materials, product quality, technology used, consumer preference, product image, market expectations, technology utilization, innovation, business competition, production capacity, garment industry development and support from financial institutions. These attributes could be used to improve the SMEs' competitiveness in order to compete with other garment industries at the national level. Table 1 shows the competitiveness criteria and attributes of the garment SMEs.

\section{Design of Analytic Network Process Model}

The ANP model was designed to identify effects and relationship between the attributes. The inner dependence is a relationship that affects one attribute with another, and those attributes still exist within the same variable. Outer dependence relationship is a relationship that affects one attribute with another attribute. However, the attributes are contained in different variables. Table 2 describes inner dependence and outer dependence of the attributes, and weights of each attributes. The weights were calculated using super decision software. The weight value of each attribute could be used to determine the right strategy for improving the competitiveness of garment SMEs at the national level. 
Table 2. Inner dependence and Outer dependence relationship and weights of the attributes

\begin{tabular}{|c|c|c|c|c|c|}
\hline No & Criteria & No & Attributes & $\begin{array}{c}\text { Inner } \\
\text { dependence }\end{array}$ & Outer dependence \\
\hline \multirow[t]{5}{*}{1} & \multirow[t]{5}{*}{ Human resources } & 1 & Motivation of entrepreneurship & 4,5 & $7,11,13,15,16,18,19$ \\
\hline & & 2 & Minimum wage rates & $3,4,5$ & $6,14,19$ \\
\hline & & 3 & $\begin{array}{l}\text { The abundance of the national } \\
\text { product workforce }\end{array}$ & 2,5 & $6,11,14,16,18$ \\
\hline & & 4 & managerial skills & 1,2 & $7,11,12,16,18,19$ \\
\hline & & 5 & Experienced workers & $1,2,4$ & $9,10,12,14,15$ \\
\hline \multirow[t]{2}{*}{2} & \multirow[t]{2}{*}{ Financial } & 6 & Product pricing & 7 & $2,3,8,9,13,15,16,18$ \\
\hline & & 7 & Investment value & 6 & $2,3,13,16,18$ \\
\hline \multirow[t]{2}{*}{3} & \multirow[t]{2}{*}{ Material resources } & 8 & Ease of obtaining materials & 9 & 11 \\
\hline & & 9 & Product quality & 8 & $10,14,15$ \\
\hline 4 & Technology & 10 & The technology used & & $3,6,9,16,18,10$ \\
\hline \multirow[t]{4}{*}{5} & \multirow[t]{4}{*}{ Marketing } & 11 & Preferences of the consumers & $1,2,13,14$ & \\
\hline & & 12 & Product image & 11,13 & 5,10 \\
\hline & & 13 & Market Expectations & 11,12 & \\
\hline & & 14 & Utilization of technology & 11 & \\
\hline \multirow[t]{2}{*}{6} & \multirow[t]{2}{*}{ Strategy } & 15 & Innovation & 16 & $1,3,5,6,10,14$ \\
\hline & & 16 & Business competition & 15 & $\begin{array}{l}1,3,6,7,10,11 \\
13,14,18\end{array}$ \\
\hline 7 & Production & 17 & Production Capacity & & $3,4,6,10,13,14$ \\
\hline \multirow[t]{2}{*}{8} & \multirow{2}{*}{$\begin{array}{l}\text { The role } \\
\text { government }\end{array}$} & 18 & The development of garment industry & 19 & $1,4,6,11,14,16$ \\
\hline & & 19 & The Financial Institution & 18 & $2,6,7,11,16,17$ \\
\hline
\end{tabular}

Table 3. Rank of competitiveness attributes of the garment SMEs

\begin{tabular}{|l|l|l|}
\hline Rank & \multicolumn{1}{|c|}{ Attributes } & Weight \\
\hline 1 & The development of garment industry & 0.11665 \\
\hline 2 & The financial institution & 0.10594 \\
\hline 3 & Production capacity & 0.08603 \\
\hline 4 & Innovation & 0.07092 \\
\hline 5 & Business competition & 0.06917 \\
\hline 6 & Product image & 0.05068 \\
\hline 7 & Preferences of the consumers & 0.04923 \\
\hline 8 & Product quality & 0.04832 \\
\hline 9 & Market expectations & 0.04589 \\
\hline 10 & Utilization of technology & 0.04525 \\
\hline 11 & The technology used & 0.04492 \\
\hline 12 & Product pricing & 0.04261 \\
\hline 13 & Ease of obtaining materials & 0.03947 \\
\hline 14 & Investment value & 0.03592 \\
\hline 15 & managerial skills & 0.03570 \\
\hline 16 & Experienced worker & 0.03454 \\
\hline 17 & Minimum wage rates & 0.02742 \\
\hline 18 & The number of labor & 0.02580 \\
\hline 19 & Motivation of entrepreneurship & 0.02554 \\
\hline \multicolumn{2}{|c|}{ Total } & 1 \\
\hline & \multicolumn{2}{|c|}{} \\
\hline
\end{tabular}

Table 3 and Figure 1 show the ranking of attributes in the strategy of enhancing the competitiveness of the garment SMEs. Attribute with the highest weight is the development of garment industry with a value of 0.11665 ; where the respondents assumed that for 
improving the competitiveness of the national market, the development factor of the garment industry is very important. It is because the SMEs could compete with other industrial centers if they have a wide network to meet market demand. The second rank is financial institution with a value of 0.10594. Support from government' financial institutions is highly needed in developing and expanding the scale of the industry. The third attribute is production capacity with a value of 0.08603 . Consumers' demand requires high production capacity, so that the SMEs could fulfill consumers' needs. The fourth is innovation, with a weight of 0.07092. Innovation in product development is important because it allows the SMEs to follow the trend underlying the consumer demands.

The fifth attribute is business competition with a valued of 0.06917 . This indicates that a good strategy is required in order to compete with other similar products. The sixth attribute is product image with a weight value of 05068 . Product image which can be easily recognized by the public is closely related to marketing strategy. The 7 th weight is preferences of consumers at 0.04923 . The choices of consumers are significantly affect the market. Hence, a strategy is required to attract the consumers, The 8th weight is the quality of products, with a weight value of 0.04832 . Product quality is an important factor to satisfy the consumers. The 9th attribute is market expectation with a value of 0.04589 . Market expectations of garment products determine the size of the industry's development. The 10 th attribute is technology utilization at 0.04525 . The development of technology should always be monitored and applied to advance the industry center so that it could compete with enterprises with similar products.

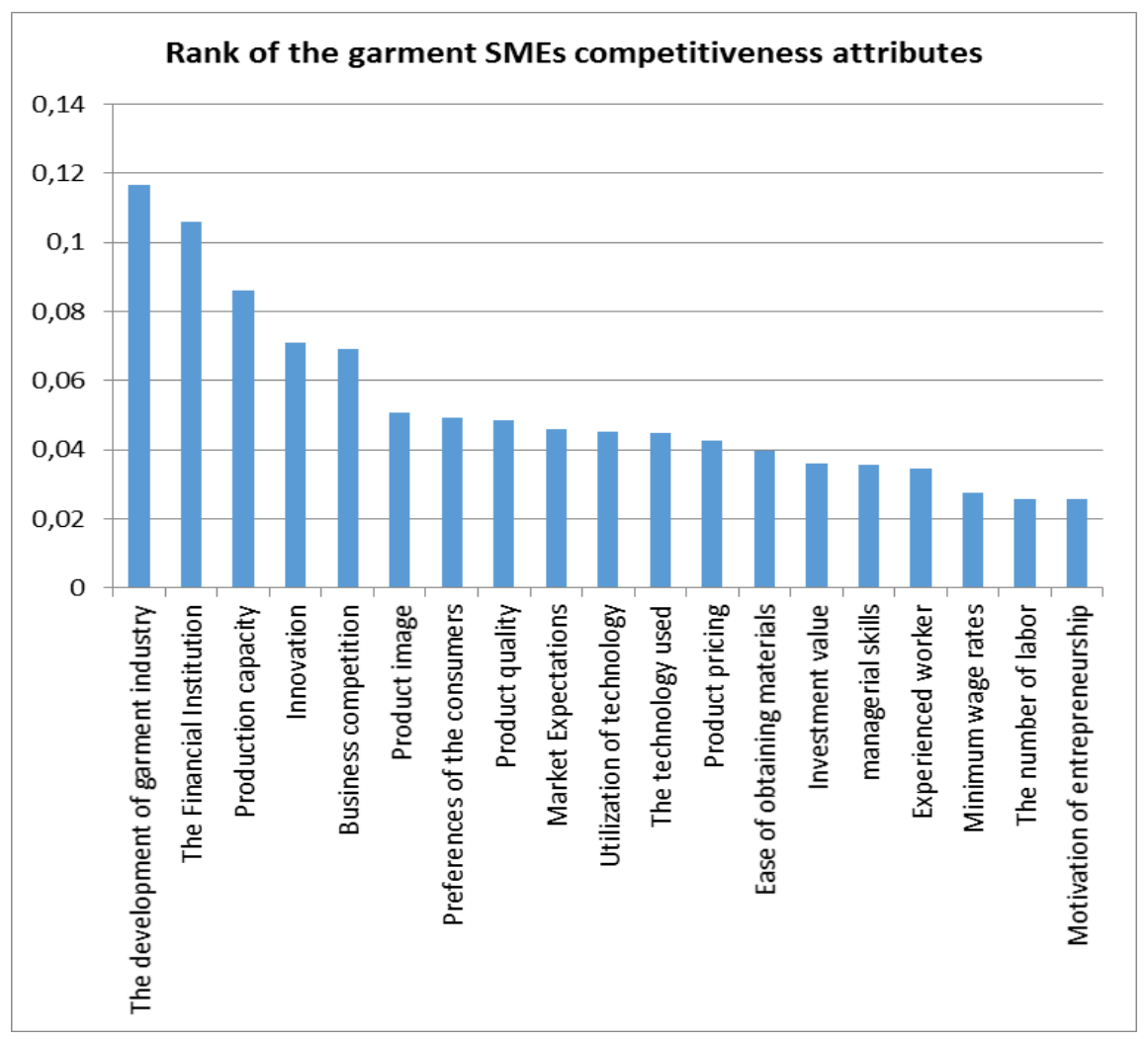

Fig. 1. Rank of the garment SMEs competitiveness attributes 
The 11th attribute is the technology used at 0.04492 . It is because in the production line, there must be a more efficient technology update to support the production capacity. The 12th attribute is pricing at 0.04261 . The price determined would affect consumer purchasing power. Therefore, the prices of products set must be affordable and competitive. The $13^{\text {th }}$ attribute is the ease of obtaining raw materials at 0.03947 . Raw material is the basic material in the production of garments. The main raw materials must be easily obtained so that the production rate can be increased. The 14th attribute is the value of investment at 0.03592 . This indicates that the development of garment industry requires a greater investment value. The 15 th attribute is managerial capability at 0.0357 . Good managerial skill will result in the increase of sales and well managed administration of the SMEs.

The 16th attribute is experienced workers at 0.03454 . The number of experienced employees would facilitate human resources capability. The 17 th attribute is the minimum wage rate at 0.03454 . The level of wage rate would affect the performance of employees. The 18th attribute is the number of labors at 0.0258 . The number of labors should be adjusted to the demand for products. The 19th attribute is entrepreneurial motivation at 0.02554 . The motivation of entrepreneurs is necessary, because a strong motivation is needed for the management and development of the SMEs.

\section{Conclusions}

The center of garment SMEs has a potential to develop its marketing at the national level. The positive contribution of the SMEs to people's economy and local revenue encourages the local government to support the SMEs in improving their performance. There were nineteen identified factors that influence the competitiveness of the SMEs. The five major factors are the development of garment industry, support from financial institution, production capacity, innovation, and business competition. This result indicated that external factors were significant factors for SMEs to capture their position and develop a strategy [11]. Further research could be conducted to determine the strategy for improving the competitiveness of the garment SMEs in order to compete with other enterprises with similar products and meet the international standard.

\section{References}

1. M. Kristiyanti, Sci. Mag. Inf., 3, 1 (2012)

2. N. A. H. N. Abdullah, S. N. M. Zain, T. I. J. Trade, Eco. and Fin 2, 4 (2011)

3. A. Arvianto, D. P. Sari, G. Olivia, Ind. Tech. J. 9, 1 (2014)

4. F. Ibrahim, M. H. Prince, A Wihartanto, KoNTekS 7 (2013)

5. R. Sukwadi, 2013, Spec. Ind. 11, 2 (2013)

6. N. S. Sari, I. Basuki, J. Stud. Tech. Edu. 2, 3 (2013)

7. W. Lestari, R. Syarief, K. Sumantadinata, J. Manag. Dev. SMI. 8, 1 (2013)

8. A. Nurzamzami, E. H. Siregar, J. Manag. Org. 5, 1 (2014).

9. M. Sugiarsana, I. Indrajaya, J. Dev. Eco. Udayana Univ. 2, (1). 2012

10. J. Jesika, Analysis of Factors Affecting the Competitiveness of Export-Oriented SMEs in DKI Jakarta. Gunadarma, (2012)

11. E. M. Şebnem, K. M. Erdilek, Proc. Soc. Behav. Sci. 150 (2014) 